\title{
Clinico, Haemato-Biochemical Changes and Therapeutic Management of Canine Babesiosis
}

\author{
B. Roopali ${ }^{1 *}$, M. $\operatorname{Roy}^{2}$ and S. Roy ${ }^{1}$ \\ ${ }^{1}$ Department of Veterinary Medicine, College of Veterinary Science \& AH, Anjora, \\ Durg (Chhattisgarh), India \\ ${ }^{2}$ Department of veterinary Physiology and Biochemistry, College of Veterinary Science \& AH, \\ Anjora, Durg (Chhattisgarh), India \\ *Corresponding author
}

\begin{tabular}{|c|c|}
\hline & A B S T R A C T \\
\hline & \multirow{6}{*}{$\begin{array}{l}\text { The present study was carried out to investigate the haemato-biochemical changes and } \\
\text { therapeutic management of canine babesiosis. Five male and } 2 \text { female dogs between } 3-4 \\
\text { years old were presented to TVCC, Veterinary College, Durg and Private Clinic, Bhillai } \\
\text { (Chhattisgarh) with a history of anorexia, tick infestation, lethargy, weakness and } \\
\text { discolouration of the urine (haemoglobinuria). Blood samples were collected from the } \\
\text { study group animals for the estimation of haemao-biochemical parameters. Haemoglobin, } \\
\text { PCV, TEC and platelets were significantly reduced in affected dogs when compared to the } \\
\text { healthy control. There was significant elevation of BUN, creatinine, ALT and globulin } \\
\text { along with significant decrease in the total protein and serum albumin levels in the affected } \\
\text { dogs. Microscopic examination of blood smear revealed pyriform shaped Babesia canis } \\
\text { and oval or signet ring form Babesia gibsoni organisms was confirmed in affected animals. } \\
\text { The infected dogs were administered single dose of inj imidocarb dipropionate (imizol }{ }^{\circledR} \text { ) } \\
\text { @ } 5 \text { mg/kg BW deep IM along with other supportive treatment. Restoration of haemato- } \\
\text { biochemical parameters were observed on } 15^{\text {th }} \text { day of post treatment and were within } \\
\text { normal physiological limits. Blood smears from the affected dogs were found to be } \\
\text { negative after } 48 \text { hours of imizol }{ }^{\circledR} \text { administration suggestive of absence of infection. }\end{array}$} \\
\hline & \\
\hline $\begin{array}{l}\text { Babesia, } \\
\text { Haemoglobinuria, } \\
\text { Anaemia, } \\
\text { Thrombocytopenia, } \\
\text { Imizol }^{\circledR} \\
\end{array}$ & \\
\hline Article Info & \\
\hline $\begin{array}{l}\text { Accepted: } \\
\text { 10 July } 2018 \\
\text { Available Online: } \\
10 \text { August } 2018\end{array}$ & \\
\hline & \\
\hline
\end{tabular}

\section{Introduction}

Canine babesiosis caused by tick-borne organisms of the genus Babesia, is one of the most significant diseases worldwide. The commonly occurring Babesia species in dogs are the Babesia canis and Babesia gibsoni (Taboada and Merchant, 1991). The Seroprevalence of babesiosis in the United States is higher in adult dogs than in dogs younger than 1 year but the lower prevalence was noted in kennels where more intensive tick controls were performed (Irwin, 2010). The immunological response plays the most important role in pathogenesis of canine babesiosis. Babesia initiates a mechanism of Antibody-mediated cytotoxic destruction of circulating erythrocytes. Autoantibodies are directed against components of the membranes of infected and uninfected 
erythrocytes. This causes intravascular and extravascular hemolysis which leads to anemia and hemoglobinemia (Irwin, 2010). The typical clinical sign observed in animals with babesiosis is hemolytic anemia (Jacobson and Clark, 1994). Parasitemia results in increased osmotic fragility of erythrocytes and serum hemolytic factors causing haemolysis (Onishi and Suzuki, 1994: Makinde and Bobade, 1994). Clinical signs of canine babesiosis include: Fever, anorexia, depression, oliguria, hemoglobinuria, vomiting, lethargy, dehydration, icterus, pale mucous membranes, spleenomegaly and dyspnea (Irwin, 2010). Haematological abnormalities include anemia, thrombocytopenia, neutropenia and lymphopenia (Furlanello et al., 2005). There are no studies about hematological and biochemical changes in dogs naturally infected with Babesia in Durg, Chhattisgarh, India. Hence, the present study was carried out to know the hematological and biochemical changes in dogs naturally infected with babesiosis and its therapeutic management.

\section{Materials and Methods}

A total of five male and two female dogs aged 3-4 years presented to the TVCC, Veterinary College, Durg and private clinic of Bhilai Chhattisgarh with a history of anorexia, tick infestation, lethargy, weakness and red coloured urine (haemoglobinuria) were included for the study.

Clinical examination of the affected dogs revealed pyrexia $\left(105.2^{\circ} \mathrm{F}\right)$, enlarged lymph nodes and pale mucous membrane. Blood samples were collected from infected animals and 15th day after the treatment of animals for preparation of blood smear, estimation of hematological and biochemical parameters

For haemato-biochemical study around $5 \mathrm{ml}$ of blood was collected in sterile vials under aseptic conditions. About $1 \mathrm{ml}$ blood of sample from each case was utilised for haematological estimation and blood smear preparation and remaining was processed for serum extraction.

Haematological parameters (haemoglobin, packed cell volume, total erythrocyte count, total leucocyte count, differential leucocyte count and platelet count) were estimated with the help of fully automated haematology cell counter- Automatic Blood Cell Counter, Model PCE 210, Manufactured by ERMA Inc., Tokyo, Japan.

Serum samples were used for the estimation of biochemical parameters like blood urea nitrogen, creatinine, total protein, albumin, and globulin by ARTOS $^{\circledR}$ semi-automatic biochemical analyser using biochemical kits of Bayer company.

The diagnosis of babesiosis was confirmed by the demonstration of parasites within the infected erythrocytes in Wright-Giemsa stained thin blood smears.

All the affected dogs were treated with single dose of inj imizol ${ }^{\circledR} \quad$ (manufactured by INTERVET)@ $5 \mathrm{mg} / \mathrm{kg}$ BW deep IM along with supportive treatment of D 25\% (dextrose 25\%) 100ml IV, melonex 2ml I/M, inj ondansetron@1mg/kg BW IV, inj neurobion $1 \mathrm{ml} \mathrm{IM}$ for 3 days and, syrup dexorange $5 \mathrm{ml}$ bid $\mathrm{P} / \mathrm{O}$ for two week.

\section{Results and Discussion}

The present study observed the clinical and haemato-biochemical changes before and after treatment. Clinical findings noted in the present study included pyrexia, haemoglobinuria, lymphadenopathy and pale mucous membrane which were in agreement with Conrad et al., (1991) and Wadhwa et al., (2011). 


\section{Haematological study}

There was a significant decrease $(\mathrm{p}<0.05)$ in the haemogram (haemoglobin, TEC and PCV) and platelet counts compared to the healthy control dogs suggestive of severe anemia and thrombocytopenia (Table 1). The hematological findings of canine babesiosis in the present study were in agreement with the findings of Furlanello et al., (2005) and Niwetpathomwat et al., (2006). It is speculated that the anemia in babesiosis resulted from an increased osmotic fragility of erythrocytes, increased erythrophagocytic activity of macrophages and immune-mediated cleavage and thrombocytopenia due to immunemediated platelets destruction (Makinde and Bobade, 1994; Onishi and Suzuki, 1994; Murase et al., 1996 and Tvedten, 2004). The mean values of leucogram in babesiosis dogs showed insignificant change when compared to healthy control group and were within the normal physiological limits whereas leukocyte abnormalities of neutopenia and lymphopenia in canine babesiosis was observed by Furlanello et al., (2005).

\section{Biochemical study}

There was a significant $(\mathrm{p}<0.05)$ increase in BUN, creatinine ALT and globulin levels in affected dogs as compared to healthy control group (Table 2). The present findings were in agreement with Salem and Farag (2014).

Significant $(p<0.05)$ increase BUN and creatinine in canine babesiosis might have resulted due to acute renal failure (Schoeman, 2009). Scally et al., (2004) reported a disproportionate rise in serum urea concentration has been related to catabolism of lysed erythrocytes. Elevation of ALT values in affected animals may be due to attributed to hepatic hypoxia in babesioses (Aysul et al., 2013). There was a significant decrease $(\mathrm{p}<0.05)$ in serum total protein and albumin levels in affected dogs due to liver damage in affected animals.

Table.1 Haematological changes in babesiosis affected dogs and treated dogs

\begin{tabular}{|l|l|l|l|}
\hline Parameter & Control group & Affected animals & $\begin{array}{l}\text { Treated animals } \\
\left(\text { on } \mathbf{1 5}^{\text {th }} \text { day }\right)\end{array}$ \\
\hline Haemoglobin (g/dL) & $14.69 \pm 0.19^{\mathrm{b}}$ & $9.09 \pm 1.11^{\mathrm{a}}$ & $13.35 \pm 1.03^{\mathrm{b}}$ \\
\hline TEC $\left(\times 10^{6} / \mu \mathrm{L}\right)$ & $6.12 \pm 0.09^{\mathrm{b}}$ & $4.11 \pm 0.32^{\mathrm{a}}$ & $5.79 \pm 0.38^{\mathrm{b}}$ \\
\hline PCV $(\%)$ & $44.55 \pm 0.89^{\mathrm{b}}$ & $29.92 \pm 2.88^{\mathrm{a}}$ & $39.12 \pm 2.77^{\mathrm{b}}$ \\
\hline Platelets $\left(\times 10^{3} / \mu \mathrm{L}\right)$ & $312.75 \pm 13.62^{\mathrm{b}}$ & $79.50 \pm 15.25^{\mathrm{a}}$ & $295.88 \pm 29.05^{\mathrm{b}}$ \\
\hline TLC $\left.\times 10^{3} / \mu \mathrm{L}\right)$ & $12.47 \pm 0.28^{\mathrm{a}}$ & $13.29 \pm 1.39^{\mathrm{a}}$ & $13.35 \pm 0.77^{\mathrm{a}}$ \\
\hline Neutrophils $(\%)$ & $63.00 \pm 0.65^{\mathrm{a}}$ & $66.75 \pm 3.35^{\mathrm{a}}$ & $64.38 \pm 1.05^{\mathrm{a}}$ \\
\hline Lymphocytes $(\%)$ & $32.63 \pm 0.82^{\mathrm{a}}$ & $28.50 \pm 3.05^{\mathrm{a}}$ & $30.63 \pm 1.45^{\mathrm{a}}$ \\
\hline Monocytes $(\%)$ & $3.53 \pm 0.35^{\mathrm{a}}$ & $3.25 \pm 0.41^{\mathrm{a}}$ & $3.38 \pm 0.32^{\mathrm{a}}$ \\
\hline Eosinophils $(\%)$ & $0.88 \pm 0.30^{\mathrm{a}}$ & $1.50 \pm 0.42^{\mathrm{a}}$ & $0.63 \pm 0.26^{\mathrm{a}}$ \\
\hline
\end{tabular}

Means bearing different superscripts differ significantly ( $\mathrm{p} \leq 0.05)$. 
Table.2 Biochemical changes in babesiosis affected and treated dogs

\begin{tabular}{|l|l|l|l|}
\hline Parameter & Control group & Affected animals & $\begin{array}{l}\text { Treated animals } \\
\left(\text { on } 15^{\text {th }} \text { day) }\right.\end{array}$ \\
\hline BUN (mg/dL) & $17.26 \pm 0.43^{\mathrm{a}}$ & $39.40 \pm 3.20^{\mathrm{b}}$ & $18.65 \pm 1.95^{\mathrm{a}}$ \\
\hline Creatinine (mg/dL) & $0.80 \pm 0.03^{\mathrm{a}}$ & $2.1 \pm 0.19^{\mathrm{b}}$ & $1.24 \pm 0.09^{\mathrm{a}}$ \\
\hline ALT (IU/L) & $67.22 \pm 2.53^{\mathrm{a}}$ & $159.82 \pm 17.73^{\mathrm{b}}$ & $77.13 \pm 7.66^{\mathrm{a}}$ \\
\hline Total protein(g/dL) & $6.97 \pm 0.09^{\mathrm{a}}$ & $5.73 \pm 0.43^{\mathrm{b}}$ & $6.67 \pm 0.15^{\mathrm{a}}$ \\
\hline Albumin (g/dL) & $3.50 \pm 0.05^{\mathrm{a}}$ & $1.53 \pm 0.19^{\mathrm{b}}$ & $3.07 \pm 0.06^{\mathrm{a}}$ \\
\hline Globulin (g/dL) & $3.47 \pm 0.06^{\mathrm{a}}$ & $4.20 \pm 0.34^{\mathrm{b}}$ & $3.60 \pm 0.14^{\mathrm{a}}$ \\
\hline
\end{tabular}

Means bearing different superscripts differ significantly $(\mathrm{p} \leq 0.05)$

\section{Diagnosis and Therapeutic management}

Microscopic examination of blood smears revealed pyriform shaped Babesia canis and oval or signet ring form Babesia gibsoni organisms in affected dogs. Imizol $^{\circledR}$ administration was found effective and blood smear examination was found negative to babesia organisms after 48 hours of treatment. Treatment restored clinical signs and the affected dogs were found stable with normal body temperature. After two weeks of treatment, the haemato-biochemical values of the affected dogs were falling within the normal physiological limits. In the present study, treatment was successful in the affected dogs with a single dose of imizol ${ }^{\circledR} @ 5 \mathrm{mg} / \mathrm{kg}$ BW deep IM along with supportive therapy whereas, Lin and Huang (2010) reported that use of triple antibiotic, that is combination of doxycycline-enrofloxacin-metronidazole with or without diminazene aceturate to treat naturally occurring canine babesiosis. Schoeman (2009) reported successful treatment of canine babesiosis with imidicarb dipropionate @ $5 \mathrm{mg} / \mathrm{kg}$ once or twice IM, 14 days apart.

The present study concluded that the the most significant abnormalities in canine babesiosis are anaemia and thrombocytopenia and a single dose of imizol ${ }^{\circledR}$ along with supportive therapy was found to be effective against canine babesiosis.

\section{References}

Aysul, N., Ural, K., Ulutas, B., Eren, H. and Karagenc, T. 2013. First detection and molecular identification of Babesia gibsoni in two dogs from the Aydin Province of Turkey. Turkish Journal of Veterinary and Animal Sciences. 37: 226-229.

Boozer, A.L. and Macintire, D.K. 2003. Canine babesiosis. Vet. Clin. North Am. Small Anim. 33:885-904.

Conrad, P., Thomford, J., Yamane I., Whiting, J., Bosma, L. and Uno, T. 1991. Hemolytic anemia caused by Babesia gibsoni infection in dogs. Journal of the American Veterinary Medical Association. 199:601-605.

Furlanello, T.F., Fiorio, M., Caldin, G., Lubas, L. and Solano G. 2005. Clinicopathological findings in naturally occurring cases of babesiosis caused by large form Babesia from dogs of Northern Italy. Vet. Parasitol. 134:77-85.

Irwin, P.J. 2010. Canine babesiosis. Vet. Clin. North Am. Small Anim. Pract. 40: 1141-1156.

Jacobson, L.S. and Clark, I.A. 1994. The pathophysiology of canine babesiosis: New approaches to an old puzzle. J. S. Afr. Vet. Assoc. 65: 134-145.

Lin, M.Y. and Huang, H.P. 2010. Use of triple antibiotic combination of 
doxycycline enrofloxacinmetronidazole combination with/ without diminazene aceturate to treat naturally occurring canine babesiosis caused by Babesia gibsoni. Acta Vet Scand. 52: 27-31

Makinde, M.O. and Bobade, P.A. 1994. Osmotic fragility of erythrocytes in clinically normal dogs and dogs with psrasites. Res Vet Sci. 57: 343-348.

Murase, T., Ueda, T., Yamato, O. and Maede, Y. 1996. Oxidative damages and enhanced ertythrophagocytosis in canine erythrocytes infected with Babesia gibsoni. J Vet Med Sci. 58: 259-261.

Niwetpathomwat, A., Techangamsuwan, S., Suvarnavibhaja, S. and Assarasakorn, S. 2006. A retrospective study of clinical hematology and biochemistry of canine babesiosis on hospital populations in Bangkok, Thailand. Comp. Clin. Pathol. 15: 110-112.

Onishi, T. and Suzuki, S. 1994. Changes of serum hemolytic activity and the number of reticulocytes in canine Babesia gibsoni infection. J. Vet. Med. Sci. 56: 611-612.

Salem, N.Y., and Farag, H.S. 2014. Clinicopathological findings in $B$. canis infected dogs in Egypt. Comp clin Pathol. 23:1305-1307.

Schoeman JP. Companion animal clinical studies. Onderstepoort Journal of Veterinary Research 2009: 76: 59-66.

Taboada, J. and Merchant, S.R. 1991. Babesiosis of companion animals and man. Vet. Clin. North Am. Small Anim. Pract. 21: 103-123.

Tvedten H. Reference Values. In: Small Animal Clinical Diagnosis by Laboratory Methods, Willard, M.D. and H. Tvedten (Eds.) 4th Edn., Elsevier, Missouri, USA. 2004, pp: 417-419.

Wadhwa, D.R., Pal, B., Mandial, R.K., Kumar, A. and Agnihotri, R.K. 2001. Clinical, haemato-biochemical and therapeutic studies of canine babesiosis in Kangra valley of Himachal Pradesh. J. Vet. Parasitol. 25(1): 39-41.

\section{How to cite this article:}

Roopali, B., M. Roy and Roy, S. 2018. Clinico, Haemato-Biochemical Changes and Therapeutic Management of Canine Babesiosis. Int.J.Curr.Microbiol.App.Sci. 7(08): 13841388. doi: https://doi.org/10.20546/ijcmas.2018.708.158 